\title{
Ross reversal: One to one, one to two, or two to two?
}

\author{
Leonard N. Girardi, MD
}

\author{
From the Department of Cardiothoracic Surgery, Weill Cornell Medical College, New York, NY. \\ Disclosures: Author has nothing to disclose with regard to commercial support. \\ Received for publication Oct 13, 2017; accepted for publication Oct 24, 2017; available ahead of print Nov 16, \\ 2017. \\ Address for reprints: Leonard N. Girardi, MD, Department of Cardiothoracic Surgery, Weill Cornell Medical Col- \\ lege, 525 E 68th St, M-424, New York, NY 10021 (E-mail: lngirard@med.cornell.edu). \\ J Thorac Cardiovasc Surg 2018;155:573-4 \\ $0022-5223 / \$ 36.00$ \\ Copyright (C) 2017 by The American Association for Thoracic Surgery \\ https://doi.org/10.1016/j.jtcvs.2017.10.061
}

In this issue of the Journal, Hussain and colleagues ${ }^{1}$ sum- $^{-}$ marize their early and midterm outcomes of autograft rescue by a procedure they call "Ross reversal." In 30 patients who had undergone a Ross procedure a mean of 12 years earlier, the autograft was harvested from its new home in the aortic root and replaced in its original anatomic position. The autografts required significant refashioning (cusp manipulations, downsizing, defect fill-in with excess autograft, aortic, or pericardial tissue) before their reattachment to the right ventricular outflow tract. All 30 patients had solid indications for autograft aortic root intervention because of either aneurysmal degeneration or significant valve dysfunction. None were deemed appropriate candidates for an attempt at either autograft valve repair or valve-sparing reimplantation. ${ }^{2}$ Of the 30,8 had significant pulmonary valve disease (6 cases of pulmonary stenosis and 2 cases of pulmonary regurgitation) that mandated intervention. Of the remaining 22 patients, 13 had mild or moderate allograft valve dysfunction, and the other 9 had no reported pathology of the pulmonary valve or artery. There were no operative deaths. At a mean follow-up duration of 4.1 years and mean echocardiographic follow-up time of 2.5 years after the Ross reversal procedure, 12 patients had evidence of postoperative reverse Ross autograft dysfunction, and half of these had moderate or more pulmonary regurgitation. Did this tour de force operation truly allow the patients to remain with 1-valve disease, or did this just change their 2 -valve disease into a different kind of 2-valve disease?

The fate of the pulmonary allograft is the critical issue here. Its performance varies among reports, but what is certain is that the long-term function of the allograft is far from perfect. The Toronto group reported that nearly half of the 212 patients after a Ross procedure had echocardiographic evidence of allograft dysfunction at 20 years. $^{3}$ Fortunately, only $7 \%$ had serious enough pulmonary valve or right ventricular issues to warrant reoperation. Similar results were reported by Kalfa and associates ${ }^{4}(5 \%$ at 10 years) and González and colleagues ${ }^{5}$ (10\% at 10 years), whereas the German-Dutch Ross registry ${ }^{6}$ reported a lower 10 -year freedom from allograft reoperation of $79 \%$.



See Article page 562.

Although these data support the premise that pulmonary valve dysfunction is well tolerated, the long-term followup on the allograft listed here should give one pause. Can the Ross procedure really be said to leave patients with 1valve disease when the patients who have undergone it require a reoperation for a valve that had nothing to do with the original disease?

It is true that less invasive transcatheter methods exist for transcatheter pulmonary valve replacement. This less invasive procedure, however, is neither benign nor a panacea. Freedom from transcatheter pulmonary valve replacement explantation at 4 years was only $89.5 \%$. More disturbing is the fact that more than $10 \%$ of patients had development of endocarditis of the transcatheter pulmonary valve replacement within the same 4 -year period. ${ }^{7}$ Hussain and colleagues ${ }^{1}$ have done a spectacular job of performing a very complicated operation successfully. It seems hard to justify taking on such a big-time operation, however, when the outcome fails to reduce significantly the percentage of patients with clinically silent but still moderate or more pulmonary valve dysfunction, whether they have a Ross reversal procedure or just take on the diseased autograft root and leave the allograft alone.

Perhaps there is a place for this procedure in treating some patients, such as the 8 in this series, with absolute indications for allograft valve replacement. Hussain and colleagues ${ }^{1}$ rightfully state that longer term follow-up will be necessary to see whether this rebuilt autograft will reset the clock on the need for reintervention on the pulmonary valve. When $10 \%$ to $20 \%$ of patients require complex 
reoperative surgery or high-risk percutaneous intervention for a native valve that was not part of the original indication for surgery, however, it is difficult to see how the Ross reversal procedure is reversing 2 -valve disease back to a 1 -valve problem.

\section{References}

1. Hussain ST, Majdalany DS, Dunn A, Stewart RD, Najm HK, Svensson LG, et al. Early and mid-term results of autograft rescue by Ross reversal: a one-valve disease need not become a two-valve disease. J Thorac Cardiovasc Surg. 2018;155: $562-72$.

2. Mookhoek A, de Her E, Bogers AJ, Takkenberg JJ, Schoof PH. Pulmonary autograft valve explants show typical degeneration. J Thorac Cardiovasc Surg. 2010; 139:1416-9.
3. David TE, David C, Woo A, Manlhiot C. The Ross procedure: outcomes at 20 years. J Thorac Cardiovasc Surg. 2014; 147:85-93.

4. Kalfa D, Feier H, Loundou A, Fraisse A, Macé L, Metras D, et al. Cryopreserved homograft in the Ross procedure: outcomes and prognostic factors. J Heart Valve Dis. 2011;20:571-81

5. Pardo González L, Ruiz Ortiz M, Delgado M, Mesa D, Villalba R, Rodriguez S, et al. Pulmonary homograft stenosis in the Ross procedure: incidence, clinical impact and predictors in long-term follow-up. Arch Cardiovasc Dis. 2017;110: 214-22.

6. Charitos EI, Takkenberg JJ, Hanke T, Gorski A, Botha C, Franke U, et al. Reoperations on the pulmonary autograft and pulmonary homograft after the Ross procedure: an update on the German Dutch Ross Registry. J Thorac Cardiovasc Surg. 2012;144:813-23.

7. Gillespie MJ, McElhinney DB, Kreutzer J, Hellenbrand WE, El-Said H, Ewert P, et al. Transcatheter pulmonary valve replacement for right ventricular outflow tract conduit dysfunction after the Ross procedure. Ann Thorac Surg. 2015;100: 996-1002; discussion 1002-3. 